\title{
A COMPREHENSIVE GEO -SPATIAL STUDY ON THE IMPACT OF SALINITY: CHALLENGES TO AGRICULTURAL YIELD IN MATLA - BIDYADHARI INTERFLUVE
}

\author{
Pinaki Sardar ${ }^{* 1}$ 价 \\ ${ }^{* 1}$ Research Scholar, Department of Geography, Sri Satya Sai University of Technology \& Medical \\ Sciences, Sehore, Bhopal - Indore Road, Madhya Pradesh, India
}

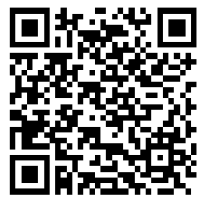

DOI: https://doi.org/10.29121/granthaalayah.v9.i1.2021.2980

Article Type: Research Article

Article Citation: Pinaki Sardar. (2021). A COMPREHENSIVE GEO SPATIAL STUDY ON THE IMPACT OF SALINITY: CHALLENGES TO AGRICULTURAL YIELD IN MATLA BIDYADHARI INTERFLUVE. International Journal of Research GRANTHAALAYAH, 9(1), 112-122. https://doi.org/10.29121/granthaa layah.v9.i1.2021.2980

Received Date: 01 January 2021

Accepted Date: 29 January 2021

Keywords:

Remote Sensing and GIS

Salinity

Soil $\mathrm{pH}$

Irrigation

\section{ABSTRACT}

Increasing salinity is a major concern to the tropical coastline agricultural system. To ensure crop production and to satisfy food requirement, land reform system should be revamped in Matla Bidyadhari interfluvial region, south 24 paraganas West Bengal. This study shows the effectiveness of GIS and Remote Sensing techniques in measuring impact of salinity on agricultural planning. The research work covers 809 sq. km area of Gosaba and Basanti Block, West Bengal. Soil samples were taken from various ground control points of these Blocks. After getting that information, soil clay fraction map, drainage map, land use map, salinity zonation map has been created by using satellite data on Arc GIS 10.6 software. These thematic maps can be use in agricultural planning. To cope with increasing salinity, it is recommended, deep water irrigation in dry season. Vegetables are more sensitive than cereal crops to salinity, so they can be yield in seasonal variation.

\section{INTRODUCTION}

To increase agricultural yielding and to satisfy food requirements land reform sequences should be revamped in Matla -Bidyadhari Interfluvial region, south 24 paraganas, West Bengal. Though this needs to assess huge quantity of spatial data, using traditional methods of surveying lands. It is also time consuming. Numerous land capability assessment techniques are used versions to the local settings of framework for Land Evaluation (FA0,2007) and centre on the sternness of land restrictions connected to crops and land use (Desmet, P., et. al., 2009). Hence the collected informations are included and organized in GIS to gain various thematic data for using in analysis process. Remote Sensing techniques are inevitable in assessing the satellite-based data sets and to realize the changes in land use patterns. As land capability assessment needs various spatial and non- spatial data (land use, topography, soil salinity etc.), GIS provides various tools to manipulate datasets into thematic maps. Now a day, soil salinity is a major concern to farmers. Crops grown in saline soil are prone to osmotic stress, nutrition disorder and toxicity, which reduce productivity. Saline stress is a major problem to cope with increasing food demand.

(C) 2021 The Author(s). This is an open access article distributed under the terms of the Creative Commons Attribution License, which permits unrestricted use, distribution, and reproduction in any medium, provided the original author and source are credited. 


\section{OBJECTIVES}

1) To indicate the potentiality of Remote Sensing in salinity measurement.

2) To investigate the spatial planning for agricultural land use settings.

3) To study how land capability plays a significant role in detecting limits in sustainable agricultural planning.

\section{STUDY AREA}

\subsection{LOCATIONAL EXTENT}

The study area is situated in south 24 paraganas, West Bengal. Basanti Block with 13 GPs and Gosaba Block with 4GPs have covered the whole region. It extends from 21029 ' $\mathrm{N}$ to $22030^{\prime} \mathrm{N}$ and 88029 ' $\mathrm{E}$ to $890 \mathrm{E}$. The area covers 809 sq. km. with Matla River in the west, Bidyadhari River in the east, Herobhanga Reserve forest in the south, and Canning - 2 Block in the north.

\section{GEOGRAPHICAL LOCATION OF STUDY AREA}

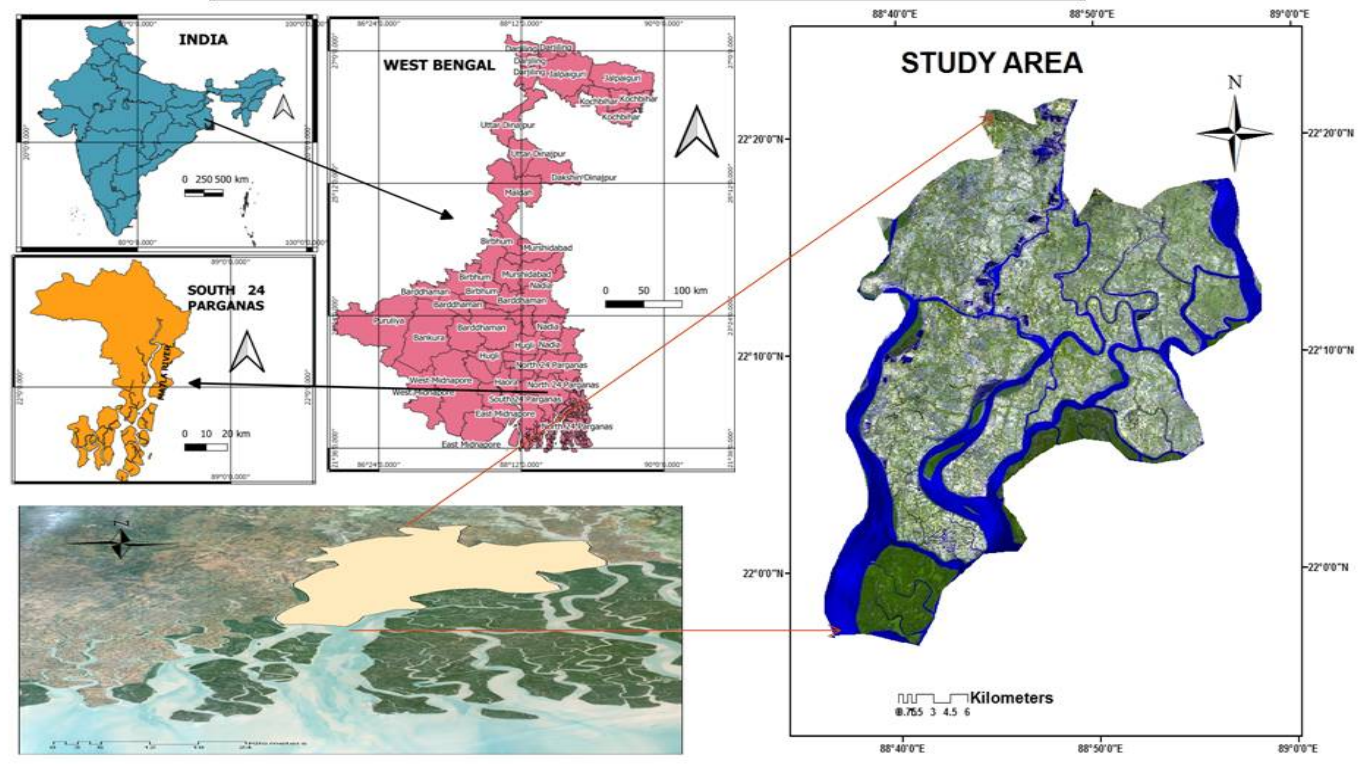

Figure 1: Location of Study Area

\subsection{GEOLOGICAL FORMATION}

This area originated during middle- upper Cretaceous period. Several subsidence and Gangetic deposition bring the recent changes in this region. The whole deltaic area has an easterly tilt, which gives the unique direction to drainage patterns.

\subsection{THE INTERFLUVIAL RIVER SYSTEM}

Matla and Bidyadhari are the two main tidal fed rivers with many distributaries, creates an estuarine river system. Ox - bow lakes, meander channel, mangrove swamp river bed islands, point bar/ charas are the various geomorphic features here. However cyclonic storms or high tidal water $(7 \mathrm{~m})$ flooded the southern part with various depths. 


\section{GLIMPSES OF STUDY AREA}

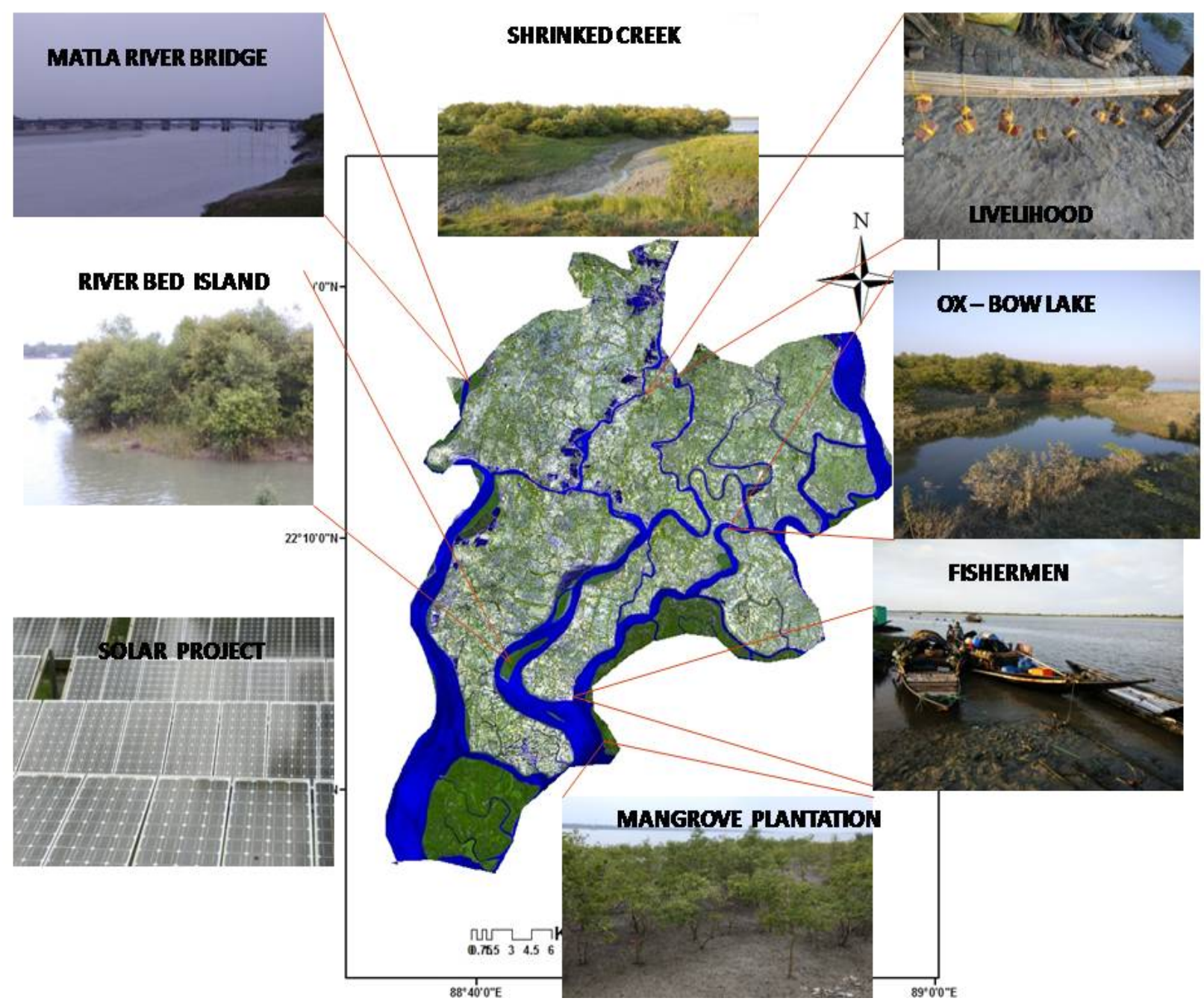

Figure 2: Some glimpses at a glance.

\subsection{SOIL TYPES}

Soils of this area are saline in nature and Azonal Type with little formed profile. Main soil types are -
a) Coarse Loamy Soil
b) Fine Loamy Soil
c) Sandy Loamy Soil
d) Silty Clay Soil
e) Silty Loamy Soil

\subsection{CLIMATIC CONDITION}

The average maximum and minimum temperature are $370 \mathrm{c}$ and $140 \mathrm{c}$. Most of the rainfall occurs during month of June to September by south - west Monsoonal wind $(400 \mathrm{~cm}-500 \mathrm{~cm})$. During March_April and October cyclonic storm develops on Bay of Bengal. 
4. METHODOLOGY

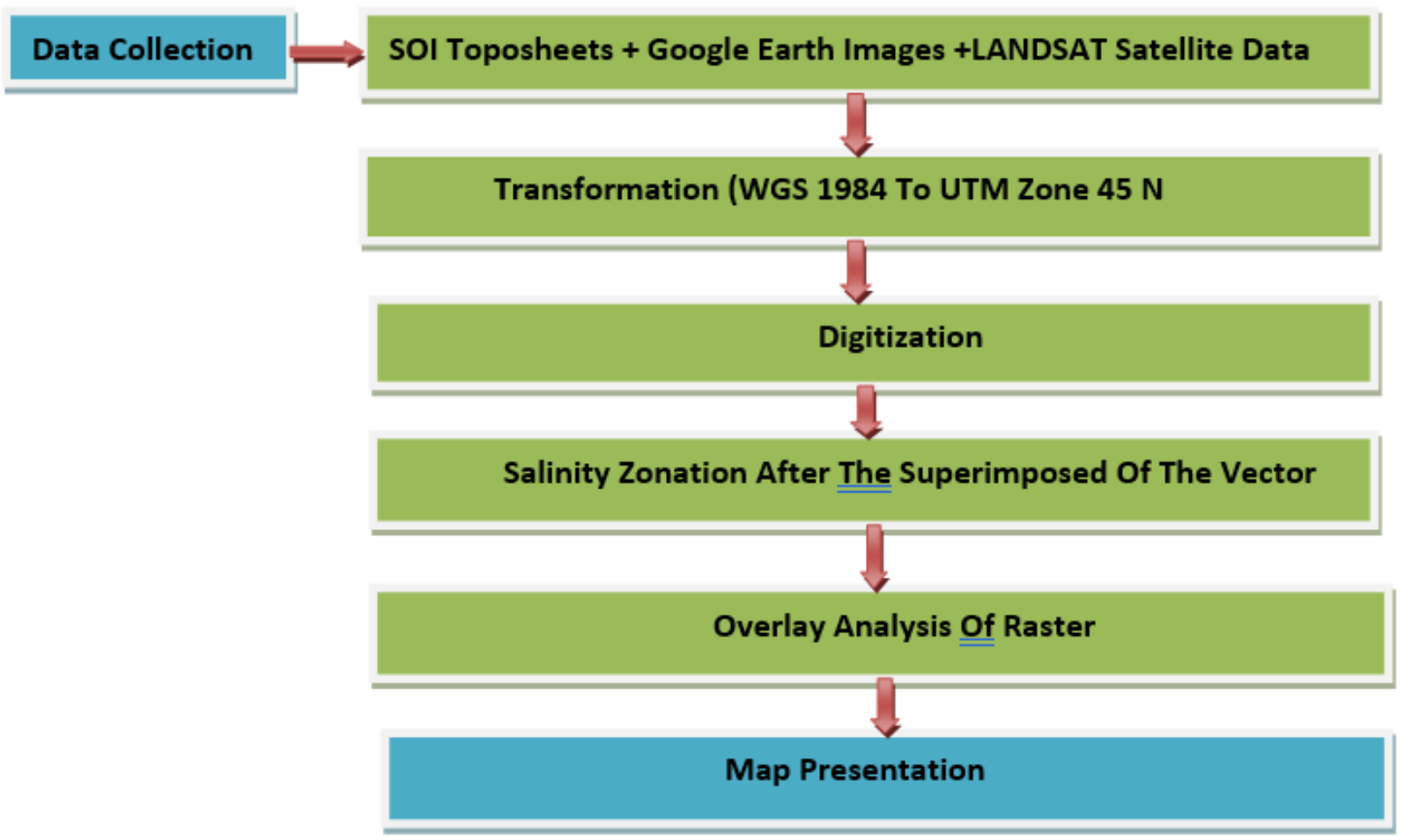

\subsection{REMOTE SENSING DATA COLLECTION AND PROCESSING}

After obtaining satellite data from USGS Earth Explorer, it has to be gone through Radiometric and Geometric corrections (atmospheric corrections by computing reflectance, registered to UTM Map Projection). Field work had been done by using 28 ground control points. Using those data NDVI and NDSI was calculated. Data classification had done by using input training samples and Maximum Likelihood method. STRM data (90 mts. Resolution) had been utilized to create DEM, Slope, and Aspect.

$$
\begin{aligned}
& \text { NDVI }=(\text { NIR }- \text { RED }) /(\text { NIR }+ \text { RED }) \quad[\text { Where, NIR = Near Infra-Red, Red = Visible Red }](\text { Equation }-1) \\
& \text { NDSI }=(\text { Green }- \text { SWIR } 1) /(\text { Green }- \text { SWIR } 1) \quad[\text { Where, Green = Visible Green, SWIR } 1=\text { Short Wave } \\
& \text { Infra-Red }] \quad \text { (Equation }-2)
\end{aligned}
$$

Table 1: Satellite data characteristics

\begin{tabular}{|c|c|c|c|c|}
\hline Satellite & Sensor & Path/Row & Year & Spatial Resolution(mts.) \\
\hline LANDSAT- 5 & TM & $139 / 46$ & $1999,2006,2010$ & 30 \\
\hline LANDSAT -7 & ETM & $139 / 46$ & 2002 & 30 \\
\hline LANDSAT - 7 & ETM+ & $139 / 46$ & 1999,2015 & 30 \\
\hline LANDSAT - 08 & OLI/TIRS & $139 / 46$ & 2014,2019 & 30 \\
\hline
\end{tabular}

\subsection{COLLECTION OF SOIL DATA}

To collect soil sample 1 meter depth bores were excavated. This was done to determine the physical and chemical properties of soil. It was tested at Soil and Salinity Research Center, Canning. Then, these informations are used to create thematic maps with Spatial Analyst Tools in Arc GIS 10.6. 


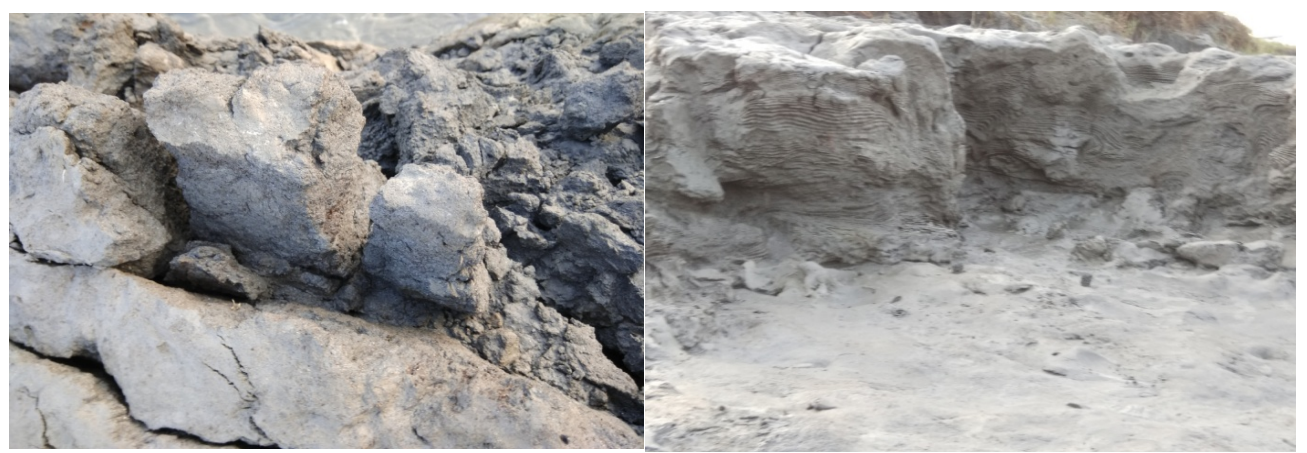

Figure 4: Saline effect on soil.

\section{RESULTS AND DISCUSSIONS}

\subsection{Landuse And Landcover}

a) Major Landuse types are - 1) Agricultural Land, 2) Fallow Land,

b) Major Landcover types are - 1) Mangrove Forest, 2) Salt Pan, 3) Marshy Land, 4) Water Bodies

The area extends 809 sq. km., among which Drainage and Marshy Land covers 183sq. km.(22.63\%) area, Fallow Land covers 163sq. km.(20.15\%) area, Salt Land covers 159sq.km.(19.65\%) area, Mangrove and Dense Forest covers 192sq.km.(23.73\%) area, and Agricultural Land covers 112sq. km.(13.84\%) area. Major cultivating crop is paddy. Besides this, tomato, beetle leaves, potato etc. are also grown by farmers. Recently many agricultural lands have converted into aqua cultural ground (shrimp, prawn fisheries).

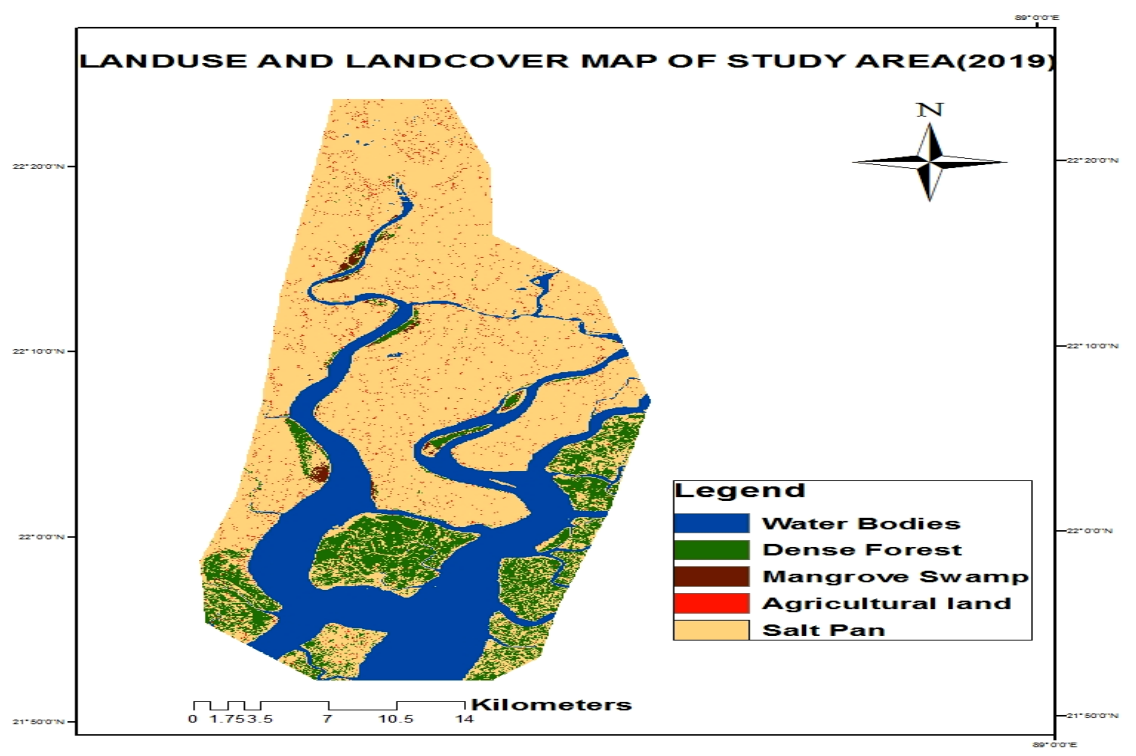

Figure 5: Land use land cover map of study area.

\subsection{Soil Texture}

To determine the surface run off, three major soil hydrological group has been identified, viz. - A, B, D.

Table 2: Hydrological Group of Soil

\begin{tabular}{|c|c|}
\hline Hydrological Group & Soil Texture \\
\hline A & Fine Loam, Coarse Loam \\
\hline B & Silt Loam \\
\hline D & Silty Clay \\
\hline
\end{tabular}


The Group A soil covers 363.61sq. Km, Group B soil covers 48.24sq.km, and the Group D soil covers 175.2 sq. $\mathrm{km}$. This reveals that Group A soil is predominating with high infiltration, which causes water logging. Organic manure may apply by Mulching Process in Sandy soils, as sandy texture features excessive water loss. Loamy texture is also able to drain excess water but unable to hold nutrients.
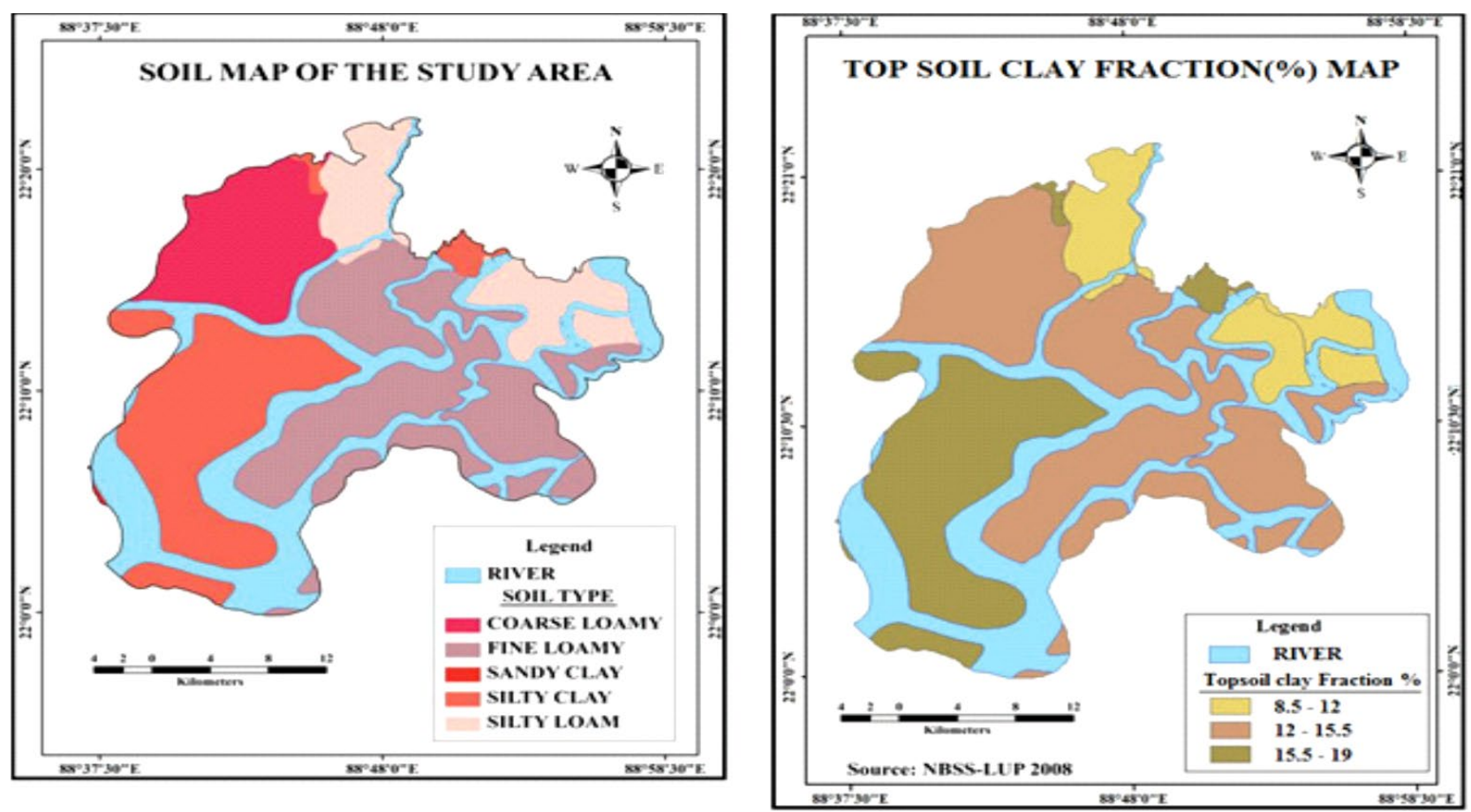

Figure 6: Physical Properties of Soil in Study Area.

\subsection{Salinity Status}

\subsubsection{DERIVING SALINITY LEVEL WITH PH}

Table 3: pH Level of Collected Soil Samples with Their Location Using GPS

\begin{tabular}{|c|c|c|c|}
\hline Places & Latitude & Longitude & $\mathrm{pH}$ \\
\hline Baria & 22.303948 & 88.750847 & 7.62 \\
\hline Jharkhali & 22.322239 & 88.785142 & 6.32 \\
\hline Bairam Chowranghee & 22.044068 & 88.664728 & 8.1 \\
\hline Ramgopalpur & 22.133235 & 88.729508 & 6.21 \\
\hline Simultala & 22.191918 & 88.755038 & 7.98 \\
\hline Majherpara & 22.201063 & 88.728365 & 5.3 \\
\hline Arampur & 22.188488 & 88.778283 & 4.5 \\
\hline Gobindapur & 22.098178 & 88.73408 & 4.52 \\
\hline Chandimore & 22.222783 & 88.825915 & 5.32 \\
\hline Bara Mullakhali & 22.248314 & 88.883073 & 5.02 \\
\hline Jyotiramghat & 22.19268 & 88.87469 & 4.02 \\
\hline Choto Mullakhali & 22.209446 & 88.925751 & 8.12 \\
\hline Kumirmari & 22.217067 & 88.941755 & 8.2 \\
\hline Punjal & 22.22507 & 88.923465 & 5.2 \\
\hline Gosaba & 22.107324 & 88.899077 & 6.04 \\
\hline Harankhali & 22.220012 & 88.641166 & 6.66 \\
\hline Harabaidya & 22.360409 & 88.797521 & 4.04 \\
\hline
\end{tabular}


On the basis of obtained $\mathrm{pH}$ values 5 Saline zonation has been created -

- Very Low (7 to >8) - Baria, Kumirmari, Choto Mullakhali, Bairam Chowranghee, Simultala etc.

- Low (6 to 7) - Harankhali, Gosaba, Ramgopalpur, Jharkhali etc.

- Moderate (5 to 6) - Punjal, Bara Mullakhali, Chandimore, Majherpara etc.

- High and Very High (4 to 5) - Harabaidya, Jyotiramghat, Gobindapur, Arampur etc.

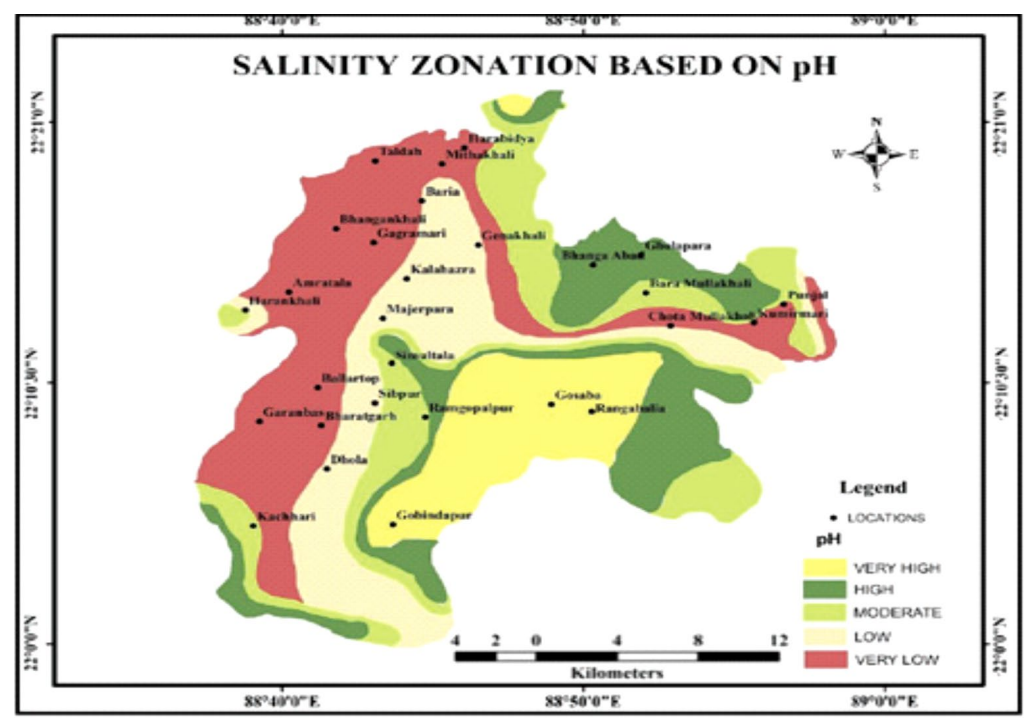

Figure 7: Salinity Zones at the Study Area (based on pH Level).

\subsubsection{DERIVING SALINITY LEVEL WITH ELECTRICAL CONDUCTIVITY (DS/M)}

Table 4: Electrical Conductivity and Sodium absorption ratio Of GCP Points

\begin{tabular}{|c|c|c|}
\hline Places & Electrical Conductivity[ds/m) & SAR \\
\hline Baria & 1.72 & 199 \\
\hline Jharkhali & 4.03 & 298.6 \\
\hline Bairam Chowranghee & 0.13 & 9.73 \\
\hline Ramgopalpur & 0.34 & 19.73 \\
\hline Simultala & 0.91 & 194.2 \\
\hline Majherpara & 0.71 & 40.1 \\
\hline Arampur & 1.02 & 68.3 \\
\hline Gobindapur & 1.06 & 42.6 \\
\hline Chandimore & 1.72 & 241.4 \\
\hline Bara Mullakhali & 0.34 & 22.44 \\
\hline jyotiramghat & 2.06 & 44.8 \\
\hline Choto Mullakhali & 1.5 & 253 \\
\hline Kumirmari & 1.89 & 317.5 \\
\hline Punjal & 1.02 & 190.2 \\
\hline Gosaba & 4.22 & 253.8 \\
\hline Harankhali & 3.12 & 30.2 \\
\hline Harabaidya & 1.01 & 50.1 \\
\hline
\end{tabular}

To measure the salinity status electrical conductivity method has been used. Salinity zonation map was made on the basis of EC using Arc GIS 10.6 software. Very high EC value concentration was found in Gosaba, Jharkhali, Harankhali, and Gobindapur. Low and Very Low EC values were in Bairam Chowranghee, Ramgopalpur, Simultala, and Bara Mullakhali. Various parameters like pH, Electrical Conductivity, Sodium Absorption Ratio has been 
obtained according to Indian Standard $(\mathrm{pH}<8.5=$ Saline Soil, $\mathrm{EC}>4=$ Saline Soil, $\mathrm{SAR}<13=$ Saline Soil, SAR $>13=$ Alkaline Soil).

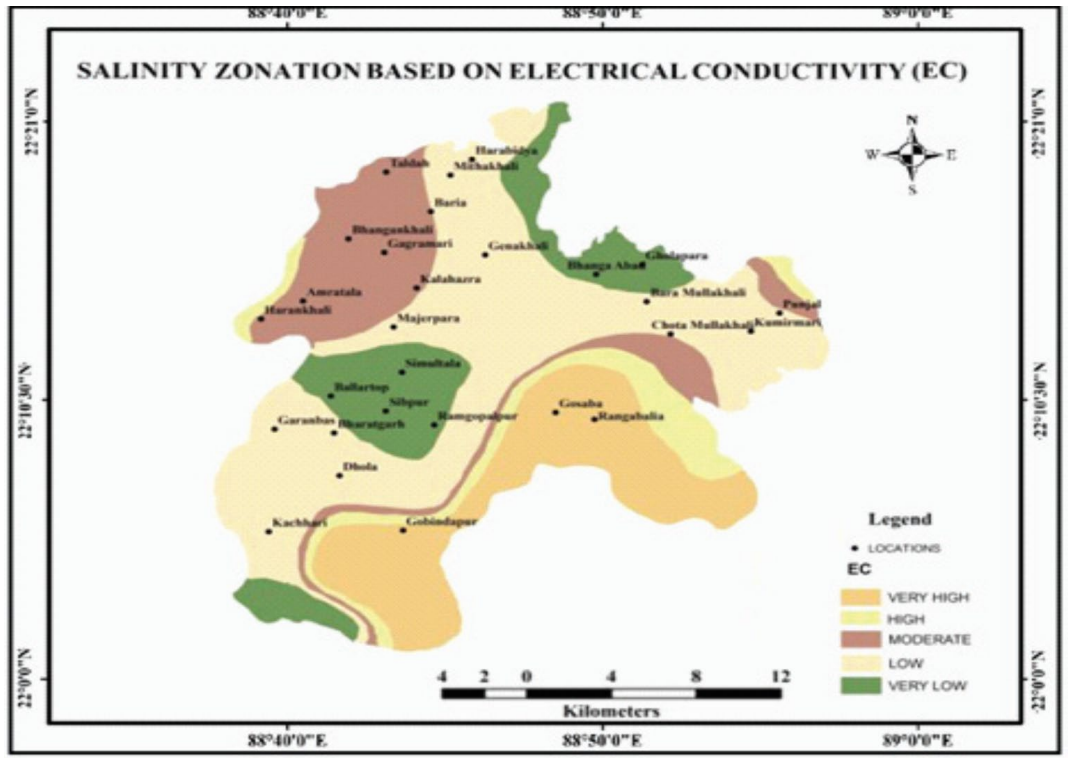

Figure 8: Salinity Zones at Study Area (based on Electrical Conductivity)

\subsection{Climatic Factors}

Fluctuation in rainfall and rise in temperature are the main causes behind climate change, which have various impacts on study area. Study reveals that increase in winter temperature creates higher evaporation rate from river surface. Also decreasing rainfall rate in dry season would result low flow situation in river. This will increase salinity level in near future. The study area receives average $475 \mathrm{~mm}$ annual rainfall. Highest temperature (420c) recorded in month of May. Generally, June to September considered as rainy season, these are the main cropping period. But rain water can be store for dry season (mainly for paddy cultivation). Another important cause is intrusion of much tidal water in river. In dry season, when amount of rainfall decreases, the river fresh water recedes, which leads to increase in salinity level.

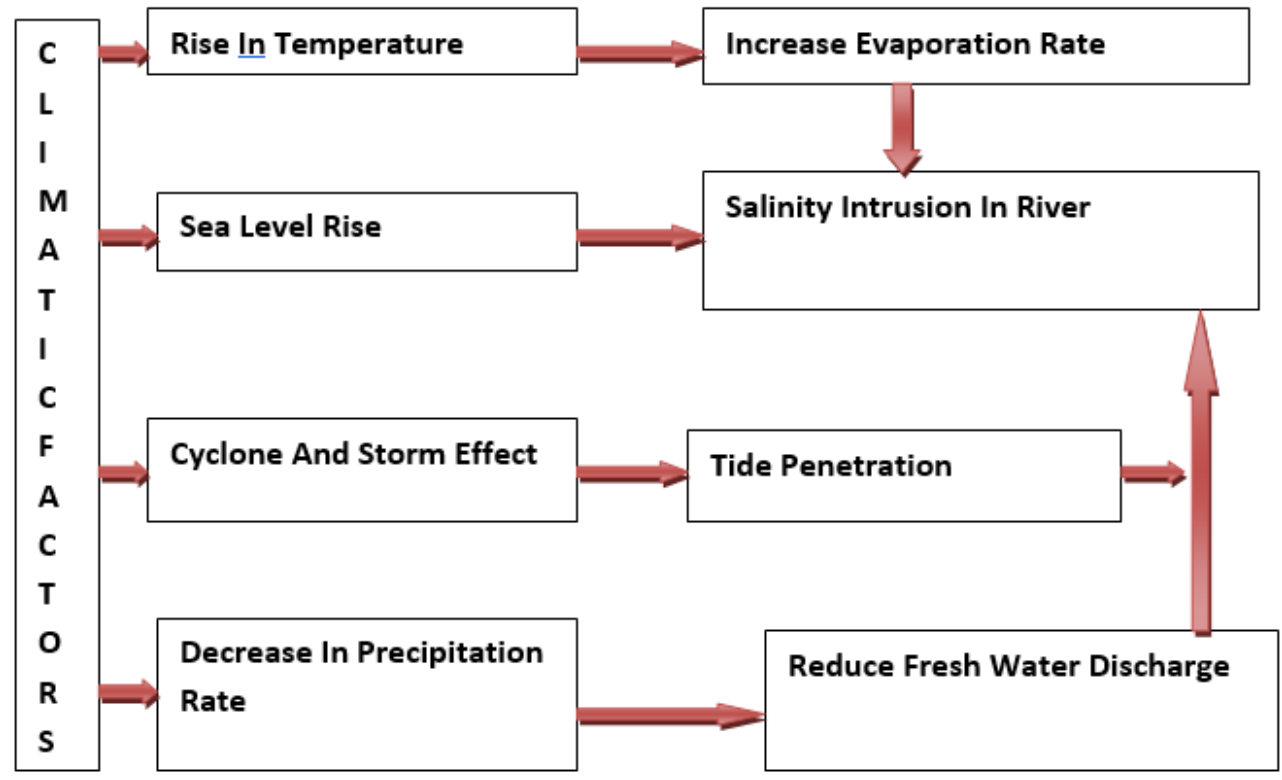

Figure 9: Simplification of salinity intrusion process. 


\section{IMPACT OF SALINITY IN RIVER WATER}

Increasing salinity in river water leads to crop reduction, decline in industrial production, and decrease in forest species productivity and increase health hazards. This is the main cause of converting many agricultural lands into aqua cultural ground. Report also reveals that saline water has negative effect on domestic cattle (reduction in milk production and reproductive health).

\section{IMPACT OF SALINITY ON AGRICULTURAL PRODUCTION}

\subsection{OSMOTIC EFFECT}

Increasing salinity lowers the level of soil water potentiality and increase salt concentration at plant root. Thus, plant cannot extract adequate amount of water from surface. This osmotic effect reduces plant growth. Higher level of EC reveals that less water availability to plant. Current study shows that $1.84 \mathrm{ds} / \mathrm{m}$ EC in irrigation water is moderately saline, according to FAO (1992).

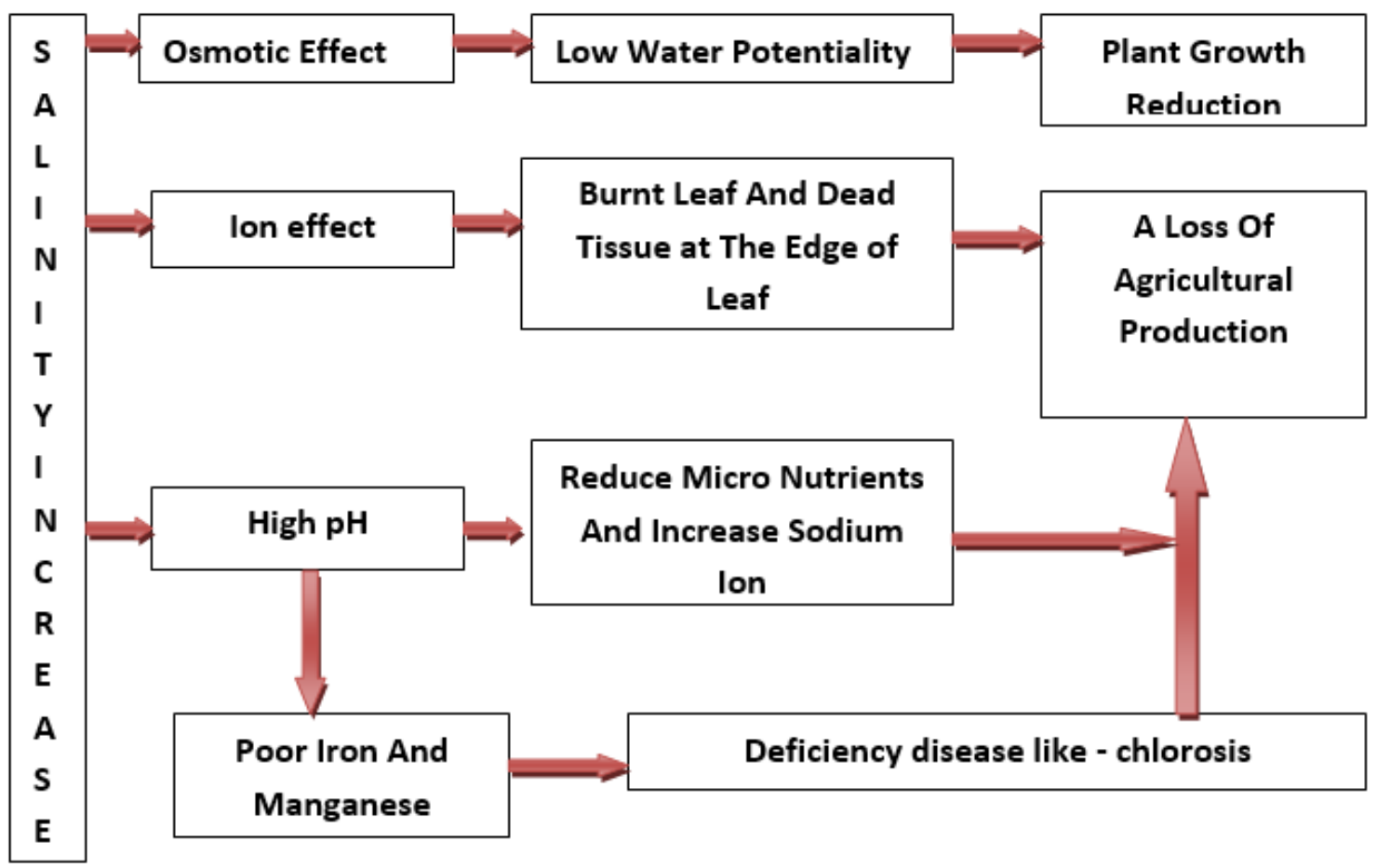

Figure 10: Effect of Salinity on Agricultural Production.

\subsection{ION EFFECT}

Higher concentration of $\mathrm{Na}$ and $\mathrm{Cl}$ may restrain plant growth. It causes burning leaf tip, reduce membrane function and hampers nutrient intake. This may happen either while the ions are extracted by the plant root or when get contacts with leaves. In this area, $\mathrm{Cl}$ concentration in irrigation water was measured as 435ppm (source: soil and salinity research centre, Canning), which reveals that crops are susceptible to ion effect. 


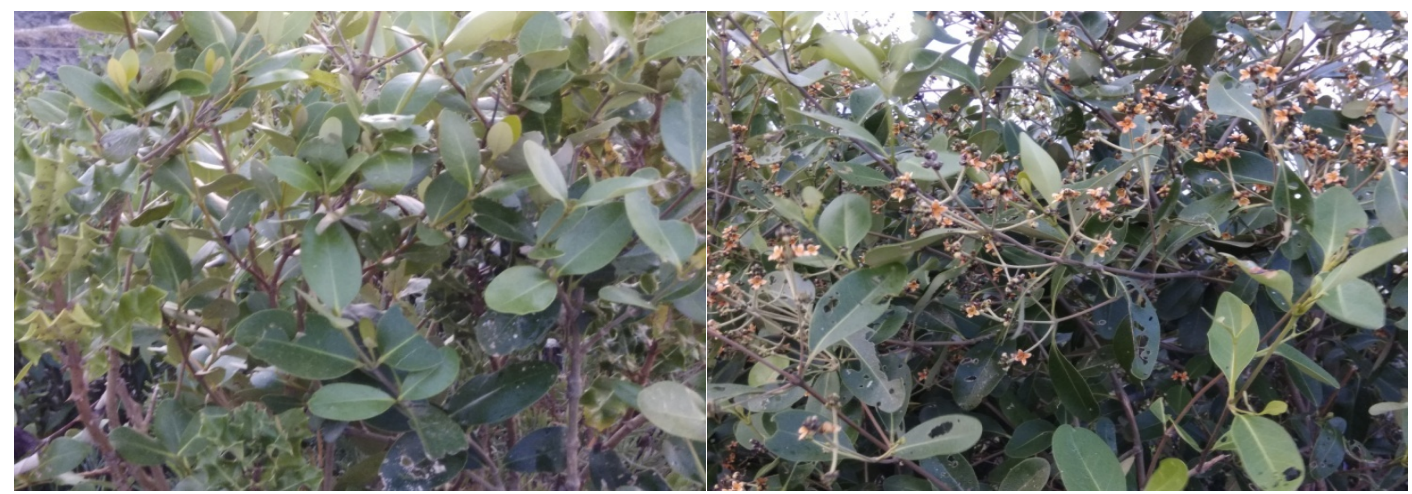

Figure 11: Burnt Leaf and Dead Tissues at the edge of leaves

\section{FARMER'S VIEWPOINT ON SALINITY}

Survey was done among households, sharecroppers, who grow Aman and Boro crops (paddy, vegetables, pulses, oilseeds, spices). According to them, salinity effects more in dry season. Productivity has been decreasing for last 7 - 9 years. $10 \%$ respondents argued that they facing fresh water crisis (drinking and irrigation), $28 \%$ reported reduction in crop size and early yellowing of leaves. According to them, vegetables are more sensitive to salinity than cereals.

\section{CONCLUSION AND RECOMMENDATIONS}

The salinity level shows an increase trend in soil and surface water in the study area. Climate change, tidal water intrusion, storm surge - all are accelerating this salinization process. Higher $\mathrm{pH}$ incorporates deficiency of phosphorous, iron etc. Appropriate fertilizer should be applied to cope with this problem. Gypsum or Calcium sulphate could be applied to release $\mathrm{Ca}$ ion and replace Na ion. Deep water irrigation can also reduce the salinity some extent. Reduction in yield will affect the livelihood, income level, and food security of local people.

\section{SOURCES OF FUNDING}

This research received no specific grant from any funding agency in the public, commercial, or not-for-profit sectors.

\section{CONFLICT OF INTEREST}

The author have declared that no competing interests exist.

\section{ACKNOWLEDGMENT}

The author expresses his gratitude to all concern officers of Soil and Salinity Research Center, Canning Town, for helping and providing necessary information. The author cordially acknowledges USGS for supplying satellite imageries. Besides, the author also thanks local people for co-operating during field survey.

\section{REFERENCES}

[1] Department of Agriculture, Forestry and Fisheries, 2010, Annual Report 2010/11, 978-0-621-40126-4, Accessed on 24-11-2014 and available from: http: // www.nda.agric.za/docs/annual report /201011/AR2011.pdf.

[2] GotWay, C.A., Ferguson, R.B., Hergert. G.W., and Peterson, T.A. 1996. Composition of Kriging and InverseDistance Methods for Mapping Soil Parameters, Soil sciences, Society of America Journal, 60, 4, 1237 - 1247. 
[3] Rashid, M. M. Haque, A.K.F. and Iftekhar, M.S. (2004) Salt Tolerances of Some Multipurpose Tree Species as Determined by Seed Germination, Journal of Biological Sciences, 4, 288- 292.

[4] Yadav, J. S. P. Sen, H.S. and Bondyopadhyay, B. K. (2009). Coastal Soils - Management for Higher Agricultural Productivity and Livelihood Security with Special Reference to India. Journal of Soil Salinity and Water Quality, 1. 1 - 13.

[5] Gowing, J.W. Tuong, T.P. and Hoanh, C. T. (2006), Land and water Management In Coastal Zones: Dealing with Agriculture - Aquaculture - Fisheries Conflicts.

[6] Amacher, J.K. Koeing, R. and Kitchen, B. (2000), Salinity and Plant Tolerance. Utah State University, No. AG So -03. Available form https://extension.usu.edu/files/publications/publication/AG-So-03.pdf

[7] Food and Agricultural Organization of the United Nations (FAO), (2011), Water Quality for Agriculture. From http://www.fao.org/DOCREP/003/T0234E/T0234E02.htm.

[8] Hoffman, H. (2010), Soil pH and Plant Health in the Home Garden, Government of Western Australia. From http://www.argic.wa.gov.au/objtwr/imported_assets/content/pw/gard/ph.pdf.

[9] FAO (2009), Land Evaluation, Land and Water Discussion, paper 6, Food and Agricultural Organization of the United Nations, Rome.

[10] Fletcher. P. C. and Veleman P. (2014), Soil Morphology as an Indicator of Seasonal High-Water Tables. From http://nesoil.com/properties/eshwt.htm

[11] Satish, A. and Niranjana, K.V. (2010), Land Sustainability Studies for Major Crops in Pavagadataluk, Karnataka using Remote Sensing and GIS Techniques. Journal of the Indian Society of Remote Sensing, 38, 143 - 151.

[12] Soil Survey Division Staff, (1993), Soil Survey Manual, Soil Conservation Service, U.S. Department of Agriculture Handbook, 18.

[13] Meghadi, N. Kamkar, B. (20011), Land Suitability Analisis for Cumin Production in the North Khorasan Province (Iran) using Geographical Information System, International Journal of Agriculture and Crop Sciences, 3, $105-110$.

[14] Kerry, R. Oliver, M.A. and Frogbrook, Z. L., (2010), Geostatistical Application for Precision Agriculture, International Journal of Applied Earth Observation and Geoinformation, 5, 35 - 64.

[15] M. R. C. and S. D. (2015), An Integrated Geo - Spatial Studies for Land Capability assessment of Agricultural Field Especially for paddy Cultivation.

[16] M. A. Baten, L. Seal, K. S. Lisa, (2015), Salinity Intrusion in Interior Coast of Bangladesh: Challenge to Agriculture in South - Central Coastal Zone, American journal of Climate Change, Vol - 04, No - 03. 